\title{
Using, Citing and Publishing Scholarly Content in the Digital Age: Case Study of Humanities Researchers
}

\author{
David Nicholas \\ CIBER Research (UK) and Tomsk State University, Russia
}

\begin{abstract}
Purpose: The research upon which this article is largely based comes from a year-long international study of trustworthiness in scholarly communications in the digital age. Essentially, the main thrust of the project was to determine the impact of the digital transition and the new products it has ushered in, such as open access publications and the social media, on academic researchers' scholarly practices. This paper focuses and reflects further on the disciplinary differences of scholarly researchers when it comes to using, citing and publishing and, especially, whether arts and humanities researchers are any different in the way they think and behave to their counterparts in the sciences and social sciences. Approach/methods: AAn international survey of over 3650 academic researchers examined how trustworthiness is determined when making decisions on scholarly reading, citing, and publishing in the digital age. The survey asked respondents whether or not they agreed with comments and quotes about scholarly behaviour obtained from pre-survey focus groups and interviews. Data from focus groups, interviews and the published literature are also used to explain further the results of the survey. Results and conclusions: In general, it was found that traditional methods and criteria remain important across the board. That is, researchers have moved inexorably from a print-based system to a digital system, but have not significantly changed the way they decide what to trust, where to publish, what to cite or use. Social media outlets and (non-peer reviewed) open access publications are not fully trusted. However, there were some significant differences according to the discipline of the respondent and this papers focuses upon these differences by comparing the views and behaviour of arts and humanities researchers with those from other disciplines. The main findings were: a) journals and the metrics that surround them are clearly not so important to humanities scholars, but nevertheless still pretty important; b) humanities researchers take a lot more care about what they use and where content comes from; c) humanities researchers look slightly more favourably on the social media. Originality/value: As far as it is known this is the first comprehensive study of digital humanities researchers and their decisions on what they use and cite and where they choose to publish.
\end{abstract}

\section{Keywords}

Humanities. Disciplinary differences. Information seeking. Trustworthiness. Scholarly communication.

Received: 10 May 2014. Revised: 15 June 2015. Accepted: 16 June 2015.

\section{Introduction}

The research reported in this paper comes largely from a year-long international study, 'Trust and authority in scholarly communications in the light of the digital transition', which was funded by the Alfred P. Sloan Foundation (UT/CIBER, 2013). Essentially, the main 
thrust of the project was to determine the impact of the digital transition and the new products it has ushered in, such as open access publications and the social media, on academic researchers' scholarly practices.

The project's broad research questions were then:

1. How do researchers assign and calibrate authority and trustworthiness to scholarly sources and channels they used, cited and published in? The study is unusual in covering scholars as both consumers and producers.

2. Whether social media and open access publications, children of the digital world, are having an impact on traditional practices of establishing authority and trustworthiness?

This paper focuses on the behavioural differences researchers according to discipline and especially whether arts and humanities researchers ${ }^{1}$ in the digital age are any different in the way they think and behave to their counterparts in the sciences and social sciences. Previous research suggests that they do. Thus in a study conducted for the Research Information Network Nicholas and Rowlands $(2009 ; 2011)$ found significant differences in information-seeking and usage between researchers in the life sciences, physical sciences, economics and history. In particular there were large differences in the extent of e-journal usage and time spent online, the use of gateways and advanced search facilities and levels of concentration in reading in top $n$ titles. For instance, half of all life scientists used journals every day, whereas only $16 \%$ of historians did so. However, when online, historians spent more time on each visit. This is in part due to the greater length and more discursive nature of articles in history as compared to the sciences, which means that it is less easy to scan a full-text article for a single fact or figure that is not present in the abstract. Historians search for and use e-journals in ways very different from their scientific and social science colleagues. Compared, for instance, with life scientists, historians were more likely to access e-journals via Google, and to use search tools, especially menus, once they are inside the publisher's platform.

Housewright et al. (2013) offered explanations for these differences suggesting that humanities scholars: 1 ) are preoccupied with the past; 2 ) tend to research as individuals and not collaboratively; 3 ) have a marked preference for the book and monograph; 4) and partly as a consequence are more library-oriented. All factors which might lead to them being behind the digital curve. However, on the other hand, it could be argued that all scholarly behaviour is becoming standardised, by the common digital platforms that all scholars use, the tablet, smartphone and the search engine. This paper attempts to throw some light upon these issues.

\section{Methodology}

The data from this paper largely came from an international questionnaire study, which formed the major data collection instrument for the Sloan project. Six scholarly publishers agreed to send an e-mail invitation to authors and editors who have contributed to their journals. These publishers reached a wide range of academics worldwide. The survey, which was hosted on SurveyMonkey.com was conducted in the summer of 2013. Participants were asked a total of 24 questions regarding their use of scholarly information and reading habits,

\footnotetext{
${ }^{1}$ Referred to as humanities researchers throughout for brevity's sake.
} 
dissemination practices, citation practices, and personal demographics. The core of the questionnaire relied on Likert scales ranking the importance or agreement with activities, views and statements related to the trustworthiness of a source/channel in three key areas where trust is an issue - using/reading, citation, and publishing. These statements were taken from focus groups and interviews, involving nearly 200 researchers which preceded and piloted the questionnaire study. In total, 3650 researchers responded to the questionnaire, making it one of the biggest surveys of its kind. Of the 3650 respondents, the life sciences accounted for $24.5 \%$, the physical sciences $24.4 \%$, social sciences $42.9 \%$ and the humanities $7.2 \%$. The low number of humanities researchers is mainly because the funder' interest lay mainly in the social sciences and hence publishers from these disciplines, because of the interests of the funder. The 263 humanities respondents were a welcome and unexpected bonus.

Because we were not sure how many surveys were distributed to unique potential respondents, we cannot calculate a response rate (there would inevitably be an overlap). Approximately $20 \%$ declined to answer most of the demographic questions. Therefore all t-tests and ANOVAs to test for significant differences include approximately only $80 \%$ of total respondents. Statistical significance was based on the 0.05 level of significance. All the five-point Likert scales used 5 to indicate the highest level of agreement. Then mean value was calculated, and the higher the mean value means respondents rated that factors more important or agreed more strongly with that statement. With the large sample for this survey, most of the differences are statistically significant, which simply means that the difference between the means does not happen by chance. However, with the relatively small number of humanities researchers compared to those from the other disciplines it means that we need to be cautious in generalizing the humanities findings. Because of this, in the case of a number of analyses conducted, the actual effect of differences in sample size have been calculated.

\section{Results}

This paper concentrates on scholarly areas and activities where there are statistically significant differences between disciplines. For each question and analysis that follows respondents were asked to rate a list of scholarly activities on a five-point scale. By assigning a number to each point on the importance scale, it was possible to average all the responses to see which activities and criteria received the highest ranking overall. Note that a ranking of " 5 " is the highest ranking possible and " 1 " the least important. For the sake of clarity, interest and statistical robustness a mixture of ways of presenting the data have been used with in some cases the humanities being compared with the life sciences, physical sciences and social sciences and in others with just the life sciences.

\subsection{Using and reading information sources}

This is the most frequent scholarly activity and the least prescribed for researchers, so it is here where they are more likely to innovate, experiment and just do what they like. So, if we are going to see anything new, such as a narrowing of behavioural differences, it will be here that we shall see it. 


\subsubsection{Tasks associated with determining trustworthiness for usage and reading}

Researchers employ a whole range of tasks in order to determine what they should use or read as Figure 1, a spider diagram comparing life scientists with humanists, clearly demonstrates. Thirteen activities in all are listed and all are employed in one way or another. It appears then that using/reading content is far from being a straightforward activity, more a case of multi-tasking. Researchers were asked to rate the importance of the task on a scale of Extremely Important (5), Very Important (4), Important (3), Somewhat Important (2), or Not Important (1) and the mean calculated, which is shown on the figure. For this analysis effect size has been computed (see the small inner line). For effect size values $<0.1$ this mean no effect, values between 0.2 and 0.4 means a small effect, values between 0.5 and 0.7 means an intermediate effect and values equal to 0.8 or greater means large effect. Thus the differences in sample size between life scientists and humanists only have an effect on the 'checking the figures and tables' task.

Figure 1 shows that the most important task for both disciplines was checking whether the arguments and logic presented in a document are sound (4.5). For humanists this was followed by reading the entire document (4.0). It can also be seen from the figure that humanities researchers clearly run the ruler all over potential information sources because they rated six tasks as being extremely or very important. This is probably what we might have expected, in fact it comes over as good old fashioned academic detective work, which we might have associated with history researchers, for instance. There were significant disciplinary differences, most notably that life scientists rated more highly reading the abstract, checking for peer review and, unsurprisingly perhaps, checking the figures and the tables in papers.

Figure 1. Importance of tasks undertaken in order to determine usage

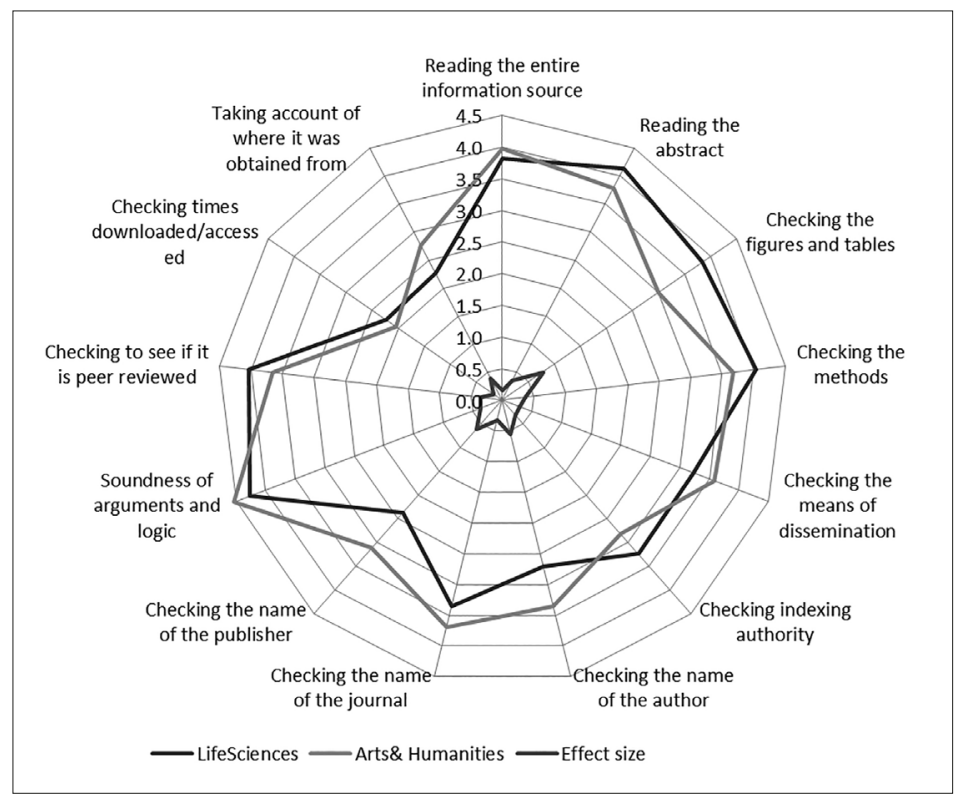




\subsubsection{Views on the trustworthiness of sources}

Table 1 examines the levels of agreement with various statements concerning the trustworthiness, or otherwise, of a range of information sources. The scale was: Strongly agree (5), Agree (4), Neither agree nor disagree (3), Disagree (2), Strongly disagree (1). The table shows that humanities scholars do not stand out in any significant way. They, like scholars from other disciplines, agreed most with the statements that I am very likely to read an article recommended by a colleague (4.06) and peer-reviewed journals are the most trustworthy information source (4.0) and also seemed to have embraced open access publishing and Wikipedia as much as the other disciplines. However, they were lukewarm regarding trust characteristics associated with metrics, such as impact factors (2.97).

Table 1: Levels of agreement with statements concerning trustworthiness of information sources for usage (in humanities ranked order)

\begin{tabular}{|l|c|c|c|c|c|}
\hline \multicolumn{1}{|c|}{ Statement } & $\begin{array}{c}\text { Life } \\
\text { Sciences }\end{array}$ & $\begin{array}{c}\text { Physical } \\
\text { Sciences }\end{array}$ & $\begin{array}{c}\text { Social } \\
\text { Sciences }\end{array}$ & Humanities & Sig* \\
\hline $\begin{array}{l}\text { 1. I am very likely to read an article } \\
\text { recommended to me by a colleague }\end{array}$ & 4.03 & 4.02 & 4.1 & 4.06 & YES \\
\hline $\begin{array}{l}\text { 2. Peer-reviewed journals are the } \\
\text { most trustworthy information source. }\end{array}$ & 4.23 & 4.13 & 4.11 & 4.0 & YES \\
\hline $\begin{array}{l}\text { 3. My main criterion for discovering } \\
\text { if a source is trustworthy is the con- } \\
\text { tent itself (whether it makes sense, } \\
\text { it is consistent with what I believe) }\end{array}$ & 3.71 & 3.8 & 3.63 & 3.78 & YES \\
\hline $\begin{array}{l}\text { 4. Open Access publications that } \\
\text { are peer reviewed are trustworthy. }\end{array}$ & 3.84 & 3.64 & 3.69 & 3.75 & YES \\
\hline $\begin{array}{l}\text { 5. Wikipedia has become more } \\
\text { trustworthy over the years. }\end{array}$ & 3.22 & 3.34 & 3.09 & 3.23 & YES \\
\hline $\begin{array}{l}\text { 6. The journal's Impact Factor is } \\
\text { important for deciding what to read. }\end{array}$ & 3.21 & 3.07 & 3.11 & 2.97 & YES \\
\hline $\begin{array}{l}\text { 7. If the information is not central } \\
\text { to my research area, the ease of ava- } \\
\text { ilability of a source is more important } \\
\text { than its quality. }\end{array}$ & 2.84 & 2.91 & 2.74 & 2.82 & YES \\
\hline $\begin{array}{l}\text { 8. When pressed for time, the ease } \\
\text { of availability of a source over-takes } \\
\text { considerations about its quality. }\end{array}$ & 2.84 & 2.85 & 2.67 & 2.68 & YES \\
\hline
\end{tabular}

*Bold indicates the highest score for each statement, which means the highest level of agreement.

\subsection{Publishing and disseminating research}

This is the activity on which academic careers and reputations are made and clearly trustworthiness is a major factor here. Researchers clearly want to publish in sources that are 
widely held to be of high status and hence trustworthy. Thus publishing focuses the academic mind on trustworthiness issues and we can learn a lot about the process by looking at researchers' choices and attitudes.

\subsubsection{Importance of outlet attributes when deciding on where to publish research}

Researchers were asked to rate outlet attributes on a scale of importance ( 5 extremely important and 1 not important). Figure 2, another spider diagram, compares the opinions of life scientists and humanities scholars. For this figure too effect size has been computed. For effect size values $<0.1$ this means no effect, values between 0.2 and 0.4 means a small effect, values between 0.5 and 0.7 means an intermediate effect and values equal to 0.8 or greater means a large effect. Thus the difference in sample size only has an intermediate effect on the 'indexed by' attribute. Figure 2 shows that for both disciplines an outlet being peer reviewed is the most important attribute, albeit more important for the life sciences (humanities $=3.87$; life sciences $=4.21$ ). There were important disciplinary differences though, with humanities researchers rating traditional scholarly publishers and the reputation of an editorial board more highly and being highly cited and indexed by a reputable database less highly.

Figure 2. Importance of publishing outlet attributes

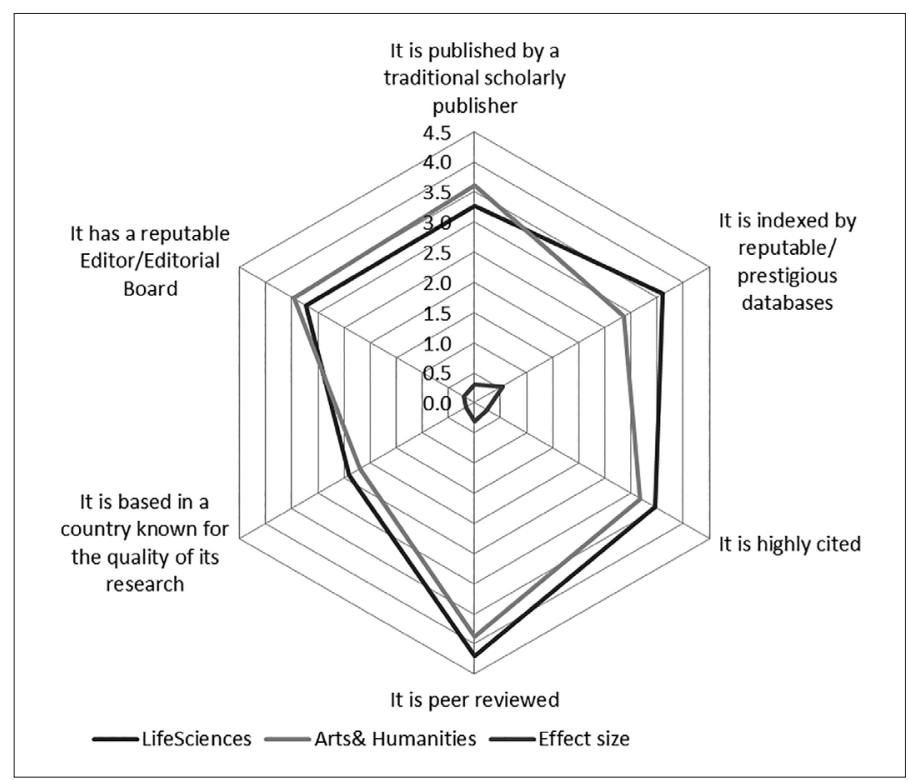

\subsubsection{Influence of institutional policies on publishing}

In today's scholarly environment the choice of where to publish is increasingly subject to influences outside a researcher's control, for instance, by institutional or government factors. In fact, over half of all researchers said they were heavily or somewhat influenced by institutional/department/government research policy directives or mandates when they 
chose a place to publish their research. This result has to be regarded as quite a big story. Those researchers who said they were influenced were presented with a list of possible pressures and asked to rate them on a scale of: Extremely (5), Very (4), Moderately (3), Slightly (2), or Not at all (1). The mean was then computed.

Humanities scholars were most likely to be pressed to publish in international journals (4.03) and to publish in traditional sources, such as journals and monographs (3.93). They were not pressed to use the social media for publishing or dissemination purposes (1.97), but there was mild pressure on them to publish in open access journals (2.53). The main disciplinary differences were that they were less likely to be pressed to publish in high impact journals (3.65 as compared to 4.05 for life scientists) and more likely to be influenced to publish in a source that is also available in both hard copy and digital forms $(2.85$ as compared to 2.19 for life scientists).

\subsubsection{Views on the trustworthiness of non-traditional publishing outlets}

Researchers were presented with a series of views/opinions about the trustworthiness of non-traditional publishing outlets and asked to rate them on a scale of: Strongly agree (5), Agree (4), Neither agree nor disagree (3), Disagree (2), Strongly disagree (1). The mean of these scores were computed (Table 2).

The table shows that no discipline were really very positive about publishing in non-traditional outlets, although depositing research in an institutional repository however was thought to be mildly beneficial. Blogs in particular were not thought to be a good way to test the veracity of ideas. There were differences between humanities researchers and those from other disciplines and the differences can be boiled down to the fact that humanities researchers are a little less antagonistic towards the social media.

Table 2: Views on the trustworthiness of non-traditional outlets (in humanities ranked order)

\begin{tabular}{|l|c|c|c|c|c|}
\hline \multicolumn{1}{|c|}{ View } & $\begin{array}{c}\text { Life } \\
\text { Sciences }\end{array}$ & $\begin{array}{c}\text { Physical } \\
\text { Sciences }\end{array}$ & $\begin{array}{c}\text { Social } \\
\text { Sciences }\end{array}$ & Humanities & Sig* \\
\hline $\begin{array}{l}\text { Depositing a version of my published } \\
\text { work in an institutional repository } \\
\text { increases usage and thereby helps } \\
\text { to build up my professional reputation. }\end{array}$ & 3.13 & 3.25 & 3.36 & 3.24 & YES \\
\hline $\begin{array}{l}\text { My own website is central for ensuring } \\
\text { the reliable dissemination of my work } \\
\text { to target audiences. }\end{array}$ & 2.69 & 2.98 & 2.87 & 2.98 & YES \\
\hline $\begin{array}{l}\text { I use social media to get out information } \\
\text { about my research because it is a reliable } \\
\text { way to reach target audiences. }\end{array}$ & 2.33 & 2.33 & 2.58 & 2.69 & YES \\
\hline $\begin{array}{l}\text { I tend to blog about the findings of my } \\
\text { research, which is a good way to test } \\
\text { the veracity of my ideas. }\end{array}$ & 2.21 & 2.34 & 2.38 & 2.4 & YES \\
\hline
\end{tabular}

*Bold indicates the highest score for each statement, which means the highest level of agreement. 


\subsection{Citing}

In terms of importance citing comes somewhere in between usage and publishing. It is a prescribed and important activity for scholars, which comes with rules, but not nearly as important as publishing. However, researchers read many articles and only cite a few of them, so selection is required and trustworthiness assessed as part of the process.

\subsubsection{Characteristic practices}

A number of citation practices were presented for the consideration of respondents and they were asked to consider how characteristic of their field each was and rate it on a five-point scale (5 most characteristic and 1 least characteristic). Note the question was not asked directly of the individual because it was felt that researchers might not answer honestly (some could be constituted as 'gaming'), but about the prevalence of the practice in their own discipline. Figure 3, a spider diagram, provides a graphic comparison of the views of life scientists and humanities scholars in respect to citing practices. For this figure effect size has been computed (small inner line). For effect size values $<0.1$ this means no effect, values between 0.2 and 0.4 means small effect, values between 0.5 and 0.7 means an intermediate effect and values equal to 0.8 or greater means large effect. Thus the differences in sample size have no impact on this analysis. The lines in the figure represent mean ratings. So you can see for example that citing the seminal work on a topic is the most common practice for both disciplines, even more so for humanists and so too is citing non-peer reviewed sources, such as blogs. Humanists appear less interested in 'gaming' by citing reviewers and self-citation.

Figure 3. Citing practices characteristic in the subject field






\subsubsection{Trustworthiness of various information sources for citing}

Researchers were asked to what extent they agreed/disagreed with a range of statements concerning the quality and trustworthiness of the sources they cite and rate them on a scale of: Strongly agree (5), Agree (4), Neither agree nor disagree (3), Disagree (2), Strongly disagree (1). The mean scores were computed (see Table 3 ). The most agreed upon statement by humanities researchers was I have no problem citing an article published in an open access journal if it has been properly peer reviewed (3.96). They are also more likely to cite open access publications and less likely to cite high impact journals.

Table 3. Views on the trustworthiness of sources for citing (in humanities ranked order)

\begin{tabular}{|l|c|c|c|c|c|}
\hline \multicolumn{1}{|c|}{ View } & $\begin{array}{c}\text { Life } \\
\text { Sciences }\end{array}$ & $\begin{array}{c}\text { Physical } \\
\text { Sciences }\end{array}$ & $\begin{array}{c}\text { Social } \\
\text { Sciences }\end{array}$ & Humanities & Sig* \\
\hline $\begin{array}{l}\text { I have no problem citing an article } \\
\text { published in an open access journal } \\
\text { if it has been properly peer reviewed. }\end{array}$ & 4.17 & 3.96 & 3.97 & 3.96 & YES \\
\hline $\begin{array}{l}\text { From a trust perspective I'm more easy- } \\
\text {-going in what I read than what I cite. }\end{array}$ & 3.62 & 3.58 & 3.73 & 3.67 & YES \\
\hline $\begin{array}{l}\text { I only cite conference proceedings } \\
\text { if there's no other alternative because } \\
\text { the work there is still speculative, } \\
\text { and, as such, a little unreliable. }\end{array}$ & 3.39 & 3.04 & 3.24 & 2.87 & YES \\
\hline $\begin{array}{l}\text { The journal impact factor is important } \\
\text { for deciding what to cite. }\end{array}$ & 2.97 & 2.86 & 2.87 & 2.66 & YES \\
\hline $\begin{array}{l}\text { I don't cite articles published } \\
\text { in Open Access journals because } \\
\text { they are of low quality. }\end{array}$ & 2.17 & 2.33 & 2.3 & 2.26 & YES \\
\hline
\end{tabular}

*Bold indicates the highest score for each statement, which means the highest level of agreement.

\subsection{Changes over time}

With so much change going on in scholarly communications respondents it was interesting to learn what researchers made of it all. Were things getting better or worse and what are the ups and downs? In order to find out researchers were asked to what extent a range of scenarios represented what has happened to their research field over the past decade. The scenarios, in ranked order agreement for humanities researchers, were as follows:

1. Closer ties with researchers in my field, enabled by digital communication, make it easier to judge the trustworthiness of sources.[positive scenario]

2. There is an increased pressure to publish and as a result, there is a flood of poor quality material. [negative scenario]

3. There are more outlets, it is easier to get published and as a result, there is a flood of poor quality material. [negative scenario] 
4. More researchers entering the field have raised standards. [positive scenario]

5. There are more unethical practices (e.g. plagiarism, falsifying, fabricating, citation gaming). [negative scenario]

6. Easily available metrics make the evaluation of trustworthiness easier. [positive scenario]

7. There is a less strict/ less rigorous peer review process and as a result, there is a flood of poor quality material. [negative scenario]

The highest ranked scenario for humanities scholars was a positive one, statement 1 , which suggests that online communities are doing a very good refereeing job, and that in a discipline noted for its lone scholars. In direct contrast the second highest ranked scenario was number 2 a distinctly negative one which refers to a tidal wave of poor quality material. From these two findings you can see how important online collaborative spaces are in combating overload and filtering out sub-standard work. There were quite a few disciplinary differences. In fact humanities scholars agreed least with the all the scenarios presented; in fact they disagreed most with three out of the seven scenarios presented (5-7). They disagreed most with the benefits of metrics, whereas life scientists were quite positive about them.

\section{Conclusions}

Generally speaking it seems not that much has changed in the scholarly world despite huge digital disruptions. From a trustworthiness perspective peer-reviewed journals are still king in the digital age and social media are little more than a bit player. However, open access content appears to be trusted, with the proviso that it is peer reviewed and published by a reputable publisher. The broad feeling is that while there is a lot more sub-standard content around, as a result of the global information explosion, there is also more quality content around as well - a fair trade off for most researchers. More specifically the main findings are:

- Usage. In regard to usage there are really not many surprises or signs of any new in scholarly behaviour emerging. In fact, what comes over most strongly is that researchers are very much involved in good old fashioned academic detective work when it came to establishing what to use or read. The main surprises are the importance of the stalwart of the pre-digital age, the abstract, and the relative lack of importance accorded to publisher for all disciplines other than the humanities. In regards to the new digital services open access sources are clearly trusted, if responsibly peer reviewed, and the positive attitude towards Wikipedia, which is mainly down to pragmatism.

- Publishing. On the whole there is not much new or changing here - traditional values and practices still hold sway and, as might have been expected, more so in the humanities. However, question marks over digital outlets seem to be a thing of the past (even in the humanities) and there are few worries about publishing in open access outlets, if peer reviewed. Perhaps, the most significant finding is the sheer pressure put on academics to publish in certain kinds of outlets and the more traditional approach of humanities scholars and the fact they find themselves most pressured to publish in international journals. 
- Citing. Again there is very traditional behaviour going on here as well with citing non-peer review sources, such as the social media, seen as not an acceptable practice. As one focus group participant mentioned it is like citing a conversation in a bar or a 'stream of consciousness'.

- Change. The biggest change to research fields over the past decade is that closer ties with researchers the field enabled by digital communication have made it easier to judge the trustworthiness of sources. This suggests that online communities are flourishing and doing a good job in managing information overload. They are the new 'gateways'.

- Humanities. Humanities researches do differ from scientists and social scientists in their behavior and perceptions and in the kinds of ways we might have expected. Thus:

a. Journals, while important, and the metrics that service them are clearly not so important to humanities scholars. While scientists are largely unquestioning about the merits of metrics; social scientists are slightly uneasy, but feel there is little choice in their use; the humanities scholars clearly feel culturally uncomfortable and alienated and respond more negatively towards them.

b. Despite the fact that researchers' information usage behavior is less prescribed and thus can be more liberal, humanities scholars take usage very seriously indeed. They take a lot more care in what they use. They are very 'picky' and inspect many internal aspects of a source and liked to see the full-text before they decide on its provenance. They do not use or like trust proxies, such as download data.

c. Names are very important to them in discerning trustworthiness - the names of editors and editorial boards, journals and publishers. And this is despite an expanding scholarly world where there are many new 'players'.

d. They are more likely to cite seminal works than the most recent ones and conferences too, but less interested in citing a source because of its (high) impact factor.

e. They agree least with the changing scholarly communications scenarios presented to them suggesting, maybe, that their field has changed the least.

But they differ in some unexpected ways as well:

f. Humanities scholars, like early career researchers, are slightly more likely to use social media, especially so to disseminate research to target audiences. The explanation for this could be linked to the following bullet.

g. The biggest and most welcome change for humanities scholars over the past decade is that closer ties with researchers in their field, enabled by digital communication, made it easier to judge the trustworthiness of material. They prefer the personal touch and as we have heard, unlike life scientists, they are no fans of a metric-driven, algorithm-governed scholarly world.

So back to the question posed at the beginning are humanities researchers losing their uniqueness because of the common use of a platform (the Internet) and search/discovery tools (Google and Google Scholar) and growing institutional-wide pressures/mandates and competition? It seems that at present the answer is in some respects, but not in all respects. However, the divide might close even further in the not too distant future because younger scholars (humanities and otherwise) behave and think differently and, possibly, more likely to find more common ground among themselves, rather than with their older disciplinary colleagues. 
Note

This article is the modified version of the paper which was presented as the opening keynote address at The Third Scientific Conference on Information Science in an age of Change, Warsaw 11th-12th May 2015.

\title{
Acknowledgments
}

Thanks to the Alfred P. Sloan Foundation for funding the original research. Also to colleagues on the 'Trust project' especially Hamid R Jamali for re-analyzing the data, Anthony Watkinson, Eti Herman, Carol Tenopir, Kenneth Levine and Rachel Volentine. The article and conference presentation was prepared with the support of Tomsk State University Competitiveness Improvement Program.

\section{References}

Housewright, R.; Schonfeld, R. C.; Wulfson, K. (2013). Ithaka S+R US Faculty Survey 2012. [14.05.2015], http://www.sr.ithaka.org/sites/default/files/reports/Ithaka_SR_US_Faculty_Survey_2012_FINAL.pdf

Nicholas, D; Rowlands, I. (2009). E-journals: their use, value and impact. London: Research Information Network. [14.05.2015], http://www.rin.ac.uk/our-work/communicating-and-disseminatingresearch/e-journals-their-use-value-and-impact

Nicholas, D; Rowlands, I. (2011). E-journals: their use, value and impact. Final Report. London: Research Information Network. [14.05.2015], http://www.rin.ac.uk/our-work/communicatingand-disseminating-research/e-journals-their-use-value-and-impact

UT/CIBER (2013). Trust and authority in scholarly communications in the light of the digital transition [14.05.2015], http://ciber-research.eu/download/20140115-Trust_Final_Report.pdf

\section{Wykorzystanie, cytowanie i publikowanie treści naukowych w erze cyfrowej: studium przypadku badaczy humanistyki}

\begin{abstract}
Abstrakt
Cel/teza: Badania, na podstawie których powstał ten artykuł, oparte są głównie na wynikach trwającego rok projektu „Zaufanie w komunikacji naukowej w erze cyfrowej”. Zasadniczą ideą projektu było ustalenie wpływu przemian cyfrowych i wprowadzanych przez nie nowych produktów, takich jak publikacje open access i media społecznościowe na praktyki naukowe środowiska akademickiego. W artykule skupiono uwagę na analizie i omówieniu dziedzinowych różnic pomiędzy badaczami dotyczących wykorzystywania, cytowania i publikowania. W szczególności zaś skupiono się na tym, czy badaczy zajmujących się humanistyką i naukami o sztuce cechuje odmienne myślenie i zachowanie od tych typowych dla badaczy nauk ścisłych i społecznych.

Koncepcja/metody badań: Na podstawie międzynarodowej ankiety, która objęła ponad 3650 nauczycieli akademickich, przebadano sposoby ustalania wiarygodności przy podejmowaniu decyzji związanych z wyborem lektur, literatury cytowanej i publikowaniem w erze cyfrowej. W ankiecie pytano respondentów, czy zgadzają się z określonymi stwierdzeniami i cytatami dotyczącymi zachowań naukowców, które uzyskano na podstawie przeprowadzonych wcześniej badań fokusowych
\end{abstract}


i wywiadów. Dane uzyskane w badaniach fokusowych, wywiadach oraz z literatury przedmiotu zostały wykorzystane do dalszego wyjaśnienia wyników ankiety.

Wyniki i wnioski: Ustalono, że tradycyjne metody i kryteria wykorzystywane przez wszystkich badaczy pozostają ważne. Nieuchronnie przenoszą się oni z systemów opartych na druku do systemów cyfrowych, ale nie zmienili w istotny sposób metod decydowania o tym, czemu ufać, gdzie publikować i co cytować lub wykorzystywać. Media społecznościowe i publikacje open access, których nie poddaje się procedurom peer-review, nie są uznawane za w pełni wiarygodne. Istnieją jednak znaczące różnice między badaczami z różnych dyscyplin i w artykule skupiono uwagę na tych różnicach, porównując poglądy i zachowania badaczy humanistyki i nauk o sztuce z tymi, które prezentują badacze innych dziedzin. Główne uzyskane wyniki były następujące: a) czasopisma i związane z nimi miary wyraźnie nie były tak bardzo ważne dla humanistów jak dla badaczy innych dziedzin, tym niemniej humaniści również wskazywali, że są istotne; b) humaniści w znacznie większym stopniu zwracają uwagę na to, co wykorzystują i skąd pochodzą wykorzystywane przez nich treści; c) humaniści nieco przychylniej patrzą na media społecznościowe.

Oryginalność/wartość poznawcza: Zgodnie z naszą wiedzą jest to pierwsze tak wyczerpujące badanie humanistów pod kątem zaufania związanego z komunikacją naukową w odniesieniu do wyboru wykorzystywanych treści, cytowania i publikowania.

\section{Słowa kluczowe}

Humanistyka. Różnice dziedzinowe. Poszukiwanie informacji. Zaufanie. Komunikacja naukowa.

Prof. DAVID NICHOLAS is a Director and founder of the internationally renowned CIBER Research Group. The group is perhaps best known for its deep log analysis techniques for monitoring online behaviours, especially in regard to the Google Generation. He is also a professor at the University of Tennessee (USA) and Tomsk State University (Russia). Previously Professor Nicholas was Head of the Department of Information Studies at University College London for seven years (2004-2011) and prior to that Head of the Department of Information Science at City University (1997-2003). His interests include use and seeking behavior in virtual spaces, the digital consumer, the virtual scholar, mobile information (information on-the-go), e-books, e-journal usage; the evaluation of digital platforms and user needs analysis. Professor Nicholas has been principal investigator on over 60 research projects, and published more than 500 peer evaluated papers and 12 books. The most important recent publications: D. Nicholas, D. Clark:. Reading' in the digital environment. Learned Publishing, 21(2) April 2012, 51-56; D. Nicholas, D. Clark \& I. Rowlands: Information on the go: case study of Europeana mobile users. Journal of the American Society of Information Science 64(7), 2013, 1311-1322; D. Nicholas, I. Rowlands, A. Watkinson, D. Brown, H. Jamali: Digital repositories ten-years on: what do scientific researchers think of them and how do they use them? Learned Publishing 2012, 25, 195-206; D. Nicholas: Dis-intermediated, decoupled and down: future of the library profession. CILIP Update, March 2012, 29-31.

Contact to the author:

Dave.Nicholas@ciber-research.eu

CIBER Research Ltd.

I Westwood Farmhouse, Newbury RG14 7RU

United Kingdom 